\title{
ERT and GPR survey of collapsed paleocave systems at the western border of the Potiguar Basin in northeast Brazil
}

\author{
João Andrade dos Reis Júnior ${ }^{1}$, David Lopes de Castro ${ }^{1 *}$, Albert Casas ${ }^{2}$, \\ Mahjoub Himi ${ }^{2}$ and Francisco Pinheiro Lima-Filho ${ }^{1}$ \\ ${ }^{1}$ Departamento de Geologia, Programa de Pós-Graduação em Geodinâmica e Geofísica - Universidade Federal do Rio Grande do \\ Norte, Campus Universitário S/N, 59078-970, Natal, Brazil \\ ${ }^{2}$ Department of Geochemistry, Petrology and Geological Prospecting, Faculty of Geology, University of Barcelona, Barcelona, Spain
}

Received January 2014, revision accepted February 2015

\begin{abstract}
Collapsed paleocave systems are carbonate reservoirs with high internal spatial complexity that are the result of several stages of karst processes. Paleocave-related reservoirs can be spread over large areas with significant thicknesses that are favourable for hydrocarbon exploration. Nevertheless, few studies have provided a detailed understanding of the strong lateral heterogeneity of these reservoirs and their complex karst-controlled development using modern karst terrain analogues. To elucidate this issue, the internal architecture of a collapsed paleocave system has been mapped accurately at the western border of the Potiguar Basin in Northeastern Brazil. The collapsed paleocaves outcrop in an escarpment that delimits the carbonate platform from the transgressive phase of the basin. Electrical resistivity tomography (ERT) and ground-penetrating radar (GPR) sections were acquired parallel and perpendicular to a road cut and served to parameterize the geophysical signatures of the collapsed paleocaves and the host rocks. The collapsed paleocaves were mapped by identifying high-resistivity zones and high-amplitude ground-penetrating radar reflectors. In contrast, the host rocks are marked by low to intermediate resistivity and ground-penetrating radar reflections that range from low amplitude to almost transparent. The resistivity data and the ground-penetrating radar attribute of the rootsquare energy enabled the mapping of the complex spatial distribution of the collapsed paleocaves system. At depths of approximately $20 \mathrm{~m}$, the paleocaves are more spread out and eventually become isolated while sometimes being connected vertically through shafts. However, at shallower levels, the paleocaves are interconnected by ducts or coalesce into a system of paleocaves that are hundreds of metres long over an area of $12000 \mathrm{~m}^{2}$. The results of the study show the detailed internal geometry of this paleocave system at a subseismic scale, which enables the identification of the connectivity pattern among these karst features and the porosity and total volume of the reservoir. This system could serve as an outcrop analogue for other collapsed paleocave carbonate reservoirs worldwide.
\end{abstract}

\section{INTRODUCTION}

Carbonate rocks are significant reservoirs of groundwater and hydrocarbons. Karst aquifers represent extensive groundwater resources around the world, supplying approximately $25 \%$ of the world population with water (Ford and Williams 2007). In the petroleum industry, more than a third of the world's hydrocarbon reserves are located in carbonate reservoirs (Bagdan and Pemberton 2004). In the last few years, this type of reservoir has become even more important because of recent discoveries of large hydrocarbon fields in carbonate rocks, particularly in the pre-salt layer that is found in the continental margins of South America and Africa (Durham 2009; Steven et al. 2010).

*david@geologia.ufrn.br
Coalesced systems of collapsed paleocaves form an important class of carbonate reservoirs that have arisen from shallow karst processes, followed by collapse, burial, and diagenesis (Loucks and Anderson 1985; McMechan et al. 1998). These systems can extend for hundreds of kilometres, with thicknesses of hundreds of metres (Loucks 1999). Typically, collapsed paleocave reservoirs involve multiple karstification and burial phases that have caused pronounced lateral and vertical heterogeneity and complex generation processes (McMechan et al. 1998; Loucks 1999). The carbonate rocks of the Ellenberger Group (Lower Ordovician) in the south central region of the United States comprise a system of collapsed paleocaves that has been intensively studied since the 1980s and represent the largest oil reservoir in West Texas (Kerans 1988; Loucks 1999; McMechan et al. 2002). In China, collapsed 
paleocave systems have been well identified in the Ordovician to Permian carbonates of the Tarim and Sichuan Basins and represent productive oil and gas reservoirs (Zeng et al. 2011; Yang et al. 2012).

The origin of epigenic limestone caves is associated with shallow karst processes in which carbonate rocks dissolve from the surface, driven by the gravitational movement of acid-rich water both in and below the vadose zone (Klimchouk 2007). These processes may progress to form extensive cave systems (Ford and Williams 2007; White 2007). The interior of these caves can be filled with material that formed due to the precipitation of dissolved calcium carbonate derived from the surrounding limestone rocks, which occurs in sub-horizontal strata (tufa). These caves can also be filled with speleothems. The term tufa is used here following Capezzuoli, Gandin, and Pedley (2014) to refer to continental carbonates that are composed primarily of calcite in a typical karst area. In addition to tufas and speleothems, sediments and organic debris that are transported from the surface through ducts may also be deposited inside the caves. As the evolutionary process of the cave continues (which is sometimes controlled by faults and joints), the caves collapse, thus generating highly fractured carbonate reservoirs. The cave infill may have high porosity and permeability, with a spatially complex internal architecture (McMechan et al. 1998; Loucks 1999).

The significant spatial heterogeneity of the collapsed paleocave reservoirs makes their characterization in deeply buried carbonate strata using seismic sections a difficult task primarily because the ducts and heterogeneities often occur on a subseismic scale. Thus, modern karst and paleocave systems are used in studies of reservoir analogues (Lucia 1995; Loucks 1999). The lower Ordovician carbonates of the El Paso Group (West Texas) contain a paleokarst system that is widely used as an analogue for the Ellenburger Group and other complex paleokarst reservoir systems (Loucks 1999; McDonnell et al. 2007). Like the paleocave system on the northwest border of the Potiguar Basin, the Nullabor Plain in South Australia is also a good candidate for an analogue for karstrelated reservoirs. According to Miller et al. (2012), the largest areal karst on the globe is a multi-stage diagenetic system, which enables the direct mapping of its complex internal geometry and contains a complete record of the climate, tectonics, and eustatic changes from the middle Miocene to the present day.

The geoelectrical method has been shown to be one of the most promising geophysical techniques for mapping karst features (Roth and Nyquist 2003; Cardarelli et al. 2006) because of the strong contrast in the resistivity between these features and the carbonate host rock. The electrical resistivity can be combined with ground-penetrating radar (GPR) surveys to correlate the variations in the resistivity with zones in the GPR sections of high and low amplitudes of electromagnetic (EM) signals, as well as to correlate areas where the greater attenuation of EM waves corresponds to areas of lower resistivity.

In this study, we report the mapping of the internal geometry of a collapsed paleocave system that is located on the western edge of a Lower Cretaceous carbonate platform in the easternmost portion of northeast Brazil (Fig. 1). Quaternary tufas were deposited on the carbonate platform and were later subjected to intense karstification, resulting in the formation of numerous caves, many of which were already collapsed. The excellent exposure of these structures along a road cut is an important opportunity for imaging the internal geometry of a collapsed paleocave system, the results of which may support similar studies on carbonate reservoirs. Highresolution GPR and geoelectric data were acquired, processed, and inverted to obtain the spatial distribution of the paleocave system and of the carbonate host rocks. The GPR and geoelectric signatures of the karst structures are discussed in the context of the changes in the physical and petrophysical properties of the sedimentary layers during the karst processes. Finally, an evolutionary model of this collapsed paleocave reservoir analogue is developed.

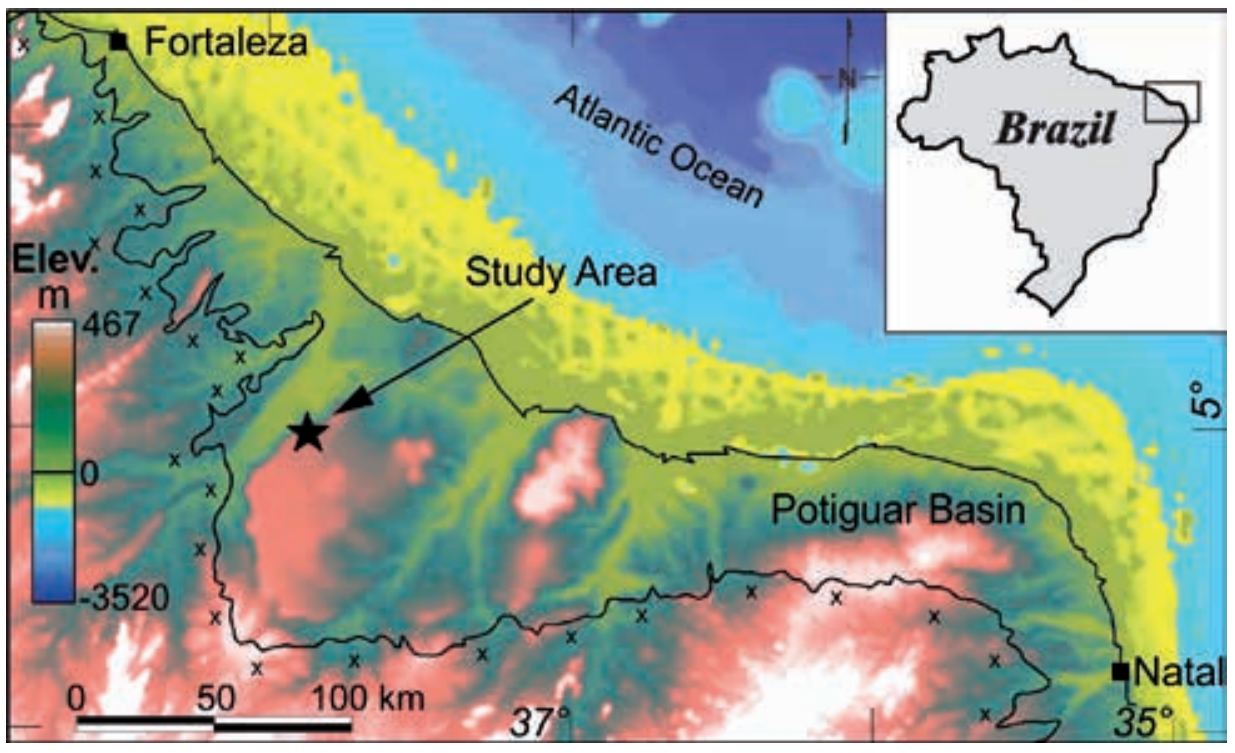

FIGURE 1

Location of the study area in the Potiguar Basin, northeast Brazil. 


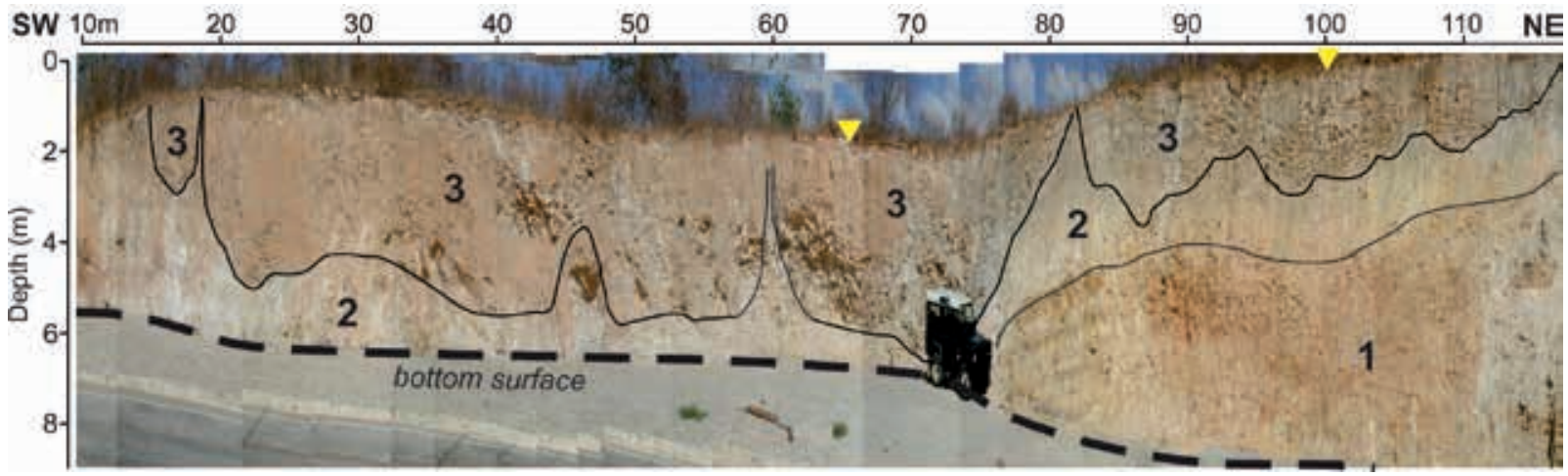

FIGURE 2

Photomosaic representative of the road cut showing three lithofacies (1 - fractured calciferous sandstone; 2 - carbonate soil; 3 - collapsed paleocaves) and the location of the CMPs (yellow triangles).

\section{GEOLOGICAL ASPECTS}

The collapsed paleocave system is located on the western border of the Potiguar Basin in Northeastern Brazil (Fig. 1). This basin of Neocomian age extends over an area of approximately $48000 \mathrm{~km}^{2}$ (considering both its emerged and submerged portions) and is surrounded to the south and the west by crystalline basement rocks (Matos 1992; Araripe and Feijó 1994). The characteristics of the sedimentary fill of the Potiguar Basin recorded the different phases of the tectonic evolution that ended with the opening of the Equatorial Atlantic (De Castro et al. 1998). The rift phase is responsible for a major graben system, which is $200 \mathrm{~km}$ in length and has depths of up to $7 \mathrm{~km}$. The displacement of extensional efforts to the north during the Barremian aborted the Potiguar rift and resulted in continental break up in the current shoreline. During the drift phase, subsidence occurred throughout the basin, followed by widespread marine transgression. In between the Turonian and Meso-Campanian periods, an extensive shallow carbonate platform formed and covered the basin with a package that is up to 600-m thick (Pessoa Neto et al. 2007). The top of this carbonate sequence (Jandaíra Formation) is shaped by an important Neocampanian unconformity that marks the end of the main transgressive sequence. Currently, tertiary and quaternary continental siliciclastic rocks partially cover the carbonate sequence, primarily in the coastal regions.

Currently, the carbonate platform has a geographical boundary in the west, which is marked by an escarpment with a maximum height of several dozen metres. There is a narrow strip of tufa above and below the escarpment that is $17 \mathrm{~km}$ long and variable in width $(285 \mathrm{~m}-780 \mathrm{~m})$ and is deposited in non-thermal waters where the complex collapsed paleocave system under study was formed (Reyes Perez et al. 2003). The studied outcrop is partially exposed on the escarpment of the carbonate platform of the Potiguar Basin.

The lower part of the outcrop exhibits a layer of fractured calciferous sandstone (Fig. 2), which is the transition zone between the lower siliciclastic (Açu Formation) and the overlying carbonate (Jandaíra Formation) sequences. This sedimentary unit is composed of medium-size sandstone layers, which are locally brecciated and cemented by calcium carbonate. These layers show low-angle stratification and cross-stratification sets (cross-bedding and tabular cross-bedding) that are tangential at the base and truncated at the top. The layers also show mud couples and clasts of clay. Above this layer is a sequence of fine limestone that underwent an intense pedogenic process to form a friable white soil (2 in Fig. 2). Prior to pedogenesis, these rocks underwent an intensive karstification process that was most likely concomitant with the tufa deposition in the upper part of the sedimentary package ( 3 in Fig. 2). The tufas were deposited as tabular strata with a slightly plane-parallel stratification that is marked by macrophyte molds.

Karstification in the carbonate platform generally produced caves over extensive regions of the Potiguar Basin. In the specific area of study, karst development also affected the tufa deposits to form a system of collapsed paleocaves that outcrop in a 2-km-narrow and 18-km-long strip along the carbonate platform escarpment (Jesus et al. 2012). The collapsed caves occupy an area of a few tens of metres and are up to $6 \mathrm{~m}$ thick. The caves are filled primarily with tufas, speleothems, and rock fragments that have collapsed from the ceiling and walls of the caves. The brecciated and fractured materials are disposed within the paleocaves in a chaotic distribution and intercalated by layers with an irregular geometry (Jesus et al. 2012).

\section{GEOPHYSICAL DATA}

The geoelectric and GPR data were collected along six profiles that were distributed throughout the studied outcrop (Fig. 3). The geophysical lines are located parallel and perpendicular to the cliff face and enabled the exposed karstified sedimentary units to be almost directly correlated with the geoelectric and GPR sections. Although many more GPR lines were surveyed (Reis Jr et al. 2014), we decided to use only the GPR sections that were acquired at the same location as the geoelectric profiles to compare the results of both geophysical methods more directly. Five common midpoint (CMP) surveys were performed to analyse the 
propagation velocity of the EM waves in the three primary lithofacies. In the present study, we present only the two CMP surveys whose velocity analyses better indicated the EM velocities of the paleocave infill and the bedrocks (CMP1 and CMP2, respectively). A differential global positioning system (GPS) was also used to determine the precise geographic position of the geophysical data and the altimetric variations along the survey lines.

\section{Electrical resistivity tomography (ERT)}

The geoelectric profiles were surveyed using a multi-electrode resistivity-metre SYSCAL Pro Switch (IRIS Instruments).

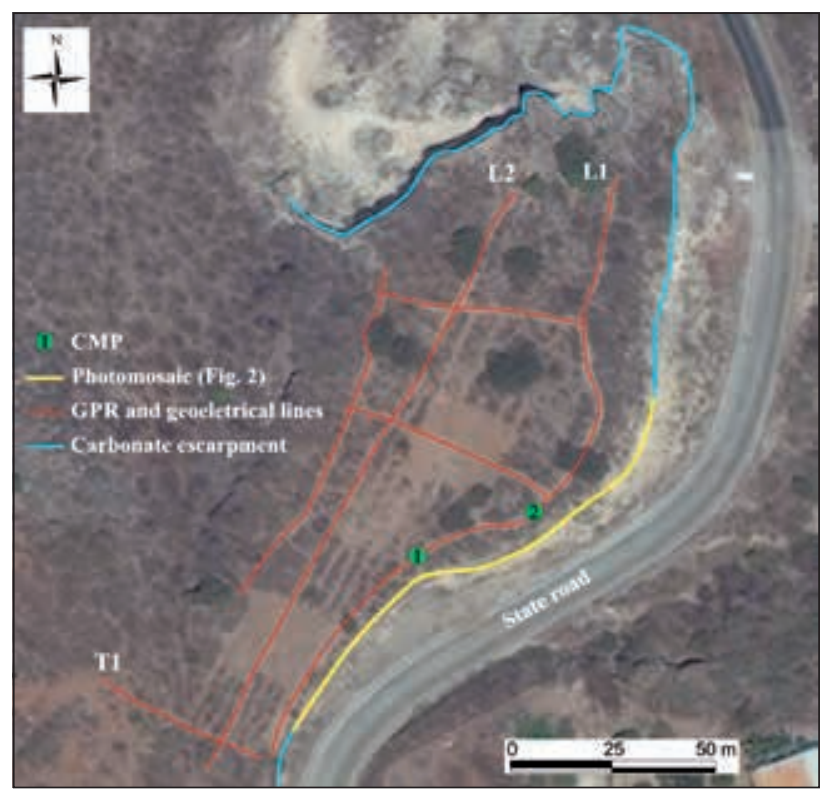

FIGURE 3

Location of the GPR and ERT profiles (red) and photomosaic (yellow) acquired in the region of the collapsed paleocave system. CMP sections (green circles) were obtained along the cliff face.
Altogether, $571 \mathrm{~m}$ of geoelectric profiles were surveyed using 48 electrodes that were spaced every $2 \mathrm{~m}$ to acquire the longer northeast-southwest lines and every $1 \mathrm{~m}$ for the shorter northwest-southeast lines. The extension of the northwest-southeast profiles to the west was limited by the boundary of a private property. We tested different electrode arrays in profile L1 (Fig. 3). The Wenner-Schlumberger array allowed for deeper investigation without compromising the resolution of the geoelectric response of the paleocaves and the sedimentary layers that were exposed along the cliff face. The Wenner-Schlumberger array enabled us to perform eight levels of investigation, which generated apparent geoelectric pseudo-sections with depths of approximately 18 and $9 \mathrm{~m}$.

The apparent electrical resistivity data that were recorded in the field were processed using RES2DINV software (Loke 2003). Like most nonlinear inversion programs, RES2DINV performs an optimization process to reduce the difference between the calculated and measured apparent resistivity values, where a covariance matrix is used to assess the accuracy of the inversion for models. The inversion routine that the program uses is based on the smoothness-constrained least-squares method (De Groot-Hedlin and Constable 1990). The average root-meansquare (RMS) error was $5.6 \%$ for a maximum of 16 iterations. Figure 4 shows the geoelectric pseudo-sections for profile L1, where there is a decrease in the resistivity of approximately $3500 \Omega \cdot \mathrm{m}$ with the depth from the surface in all of profiles. Highresistivity zones occur close to the surface that are coincident with the location of the collapsed paleocaves, revealing the geoelectric signature pattern of these karst features, whereas the carbonate host rocks have a lower resistivity in the range of $180 \Omega \cdot \mathrm{m}-1250 \Omega \cdot \mathrm{m}$ (Table 1$)$.

\section{Ground-penetrating radar (GPR)}

The GPR data were acquired using SIR-3000 equipment (GSSI Inc.) in reflection mode with $200-\mathrm{MHz}$ antennas, a time window

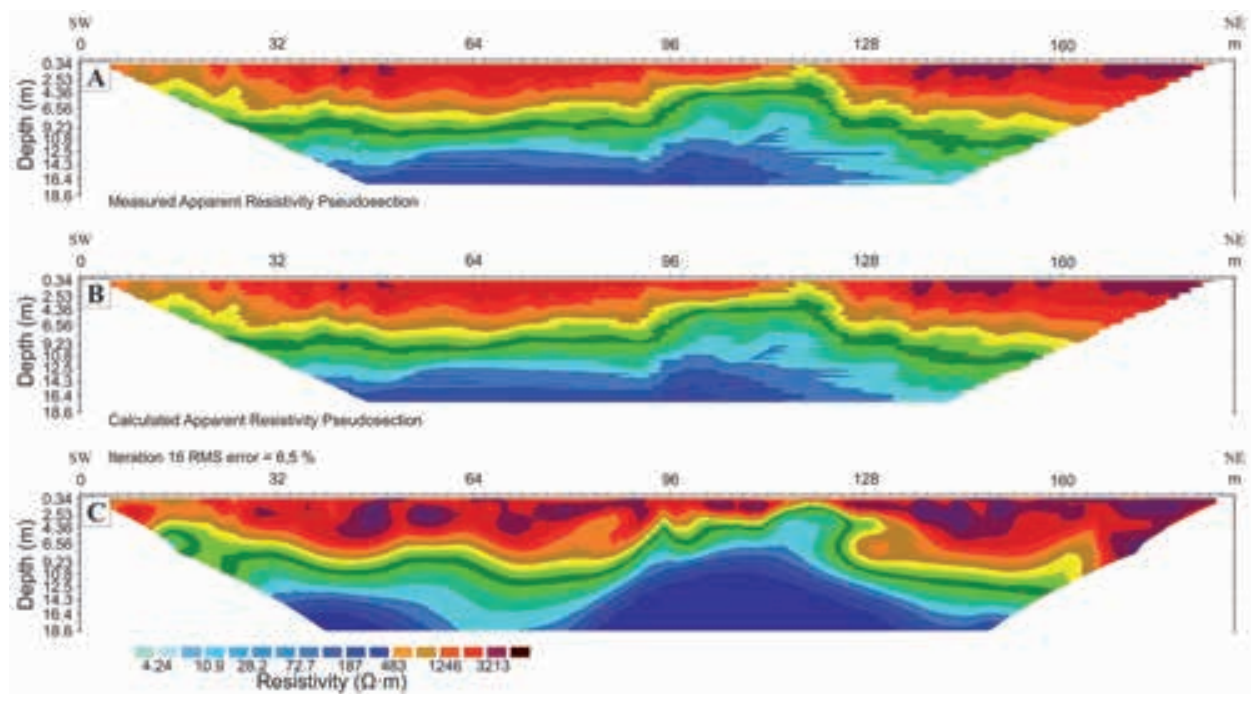

FIGURE 4

Measured apparent resistivity pseudo-section (a), calculated apparent resistivity pseudo-section (b), and inverted resistivity section of profile L1 (Fig. 3). 


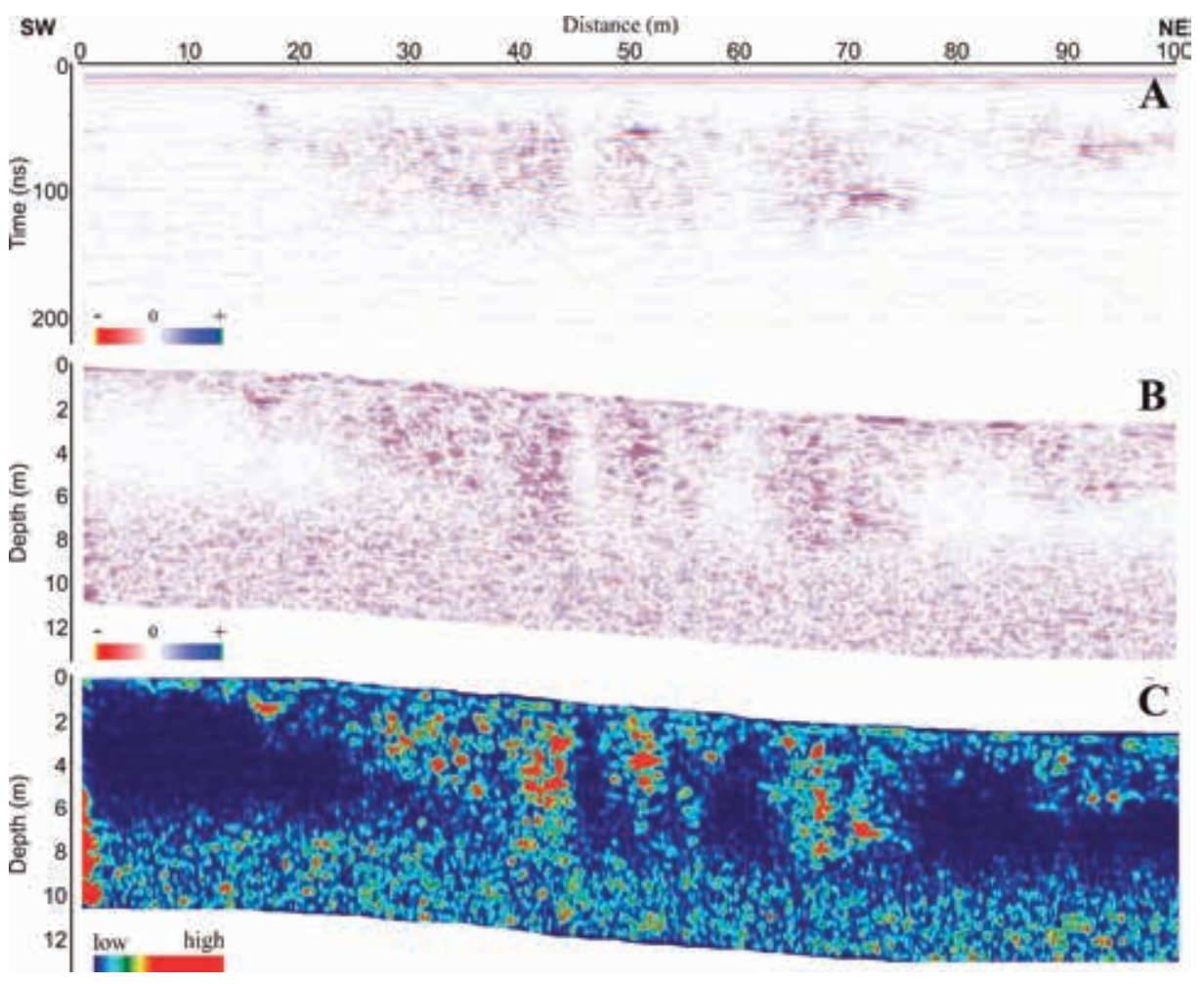

FIGURE 5

GPR section L1 original (a), processed (b), and with RS energy attribute (c).

TABLE 1

Physical and petrophysical properties of the karst features identified in the study area. $v$ : propagation velocity of EM wave (m/ns); $\varepsilon_{r}:$ relative dielectric permittivity; $\rho$ : electrical resistivity $(\Omega \cdot \mathrm{m}) ; E-R S$ : RS energy; $\phi$ : porosity in $\% ; \kappa$ : permeability in $\mathrm{mD}$.

\begin{tabular}{|c|c|c|c|c|c|c|}
\hline Carbonate features & $v$ & $\varepsilon_{\mathrm{r}}$ & $\rho$ & $E-R S$ & $\phi$ & $\kappa$ \\
\hline \multirow{2}{*}{ Collapsed paleocaves } & 0.137 & 4.8 & \multirow{2}{*}{$>1246$} & \multirow{2}{*}{$>10000$} & 40.294 & 135.6 \\
\hline & 0.134 & 5 & & & 30.285 & 129.5 \\
\hline \multirow{2}{*}{ Carbonate soil } & 0.106 & 8 & $<1246$ & \multirow{2}{*}{$<5000$} & \multirow{2}{*}{-} & \multirow{2}{*}{-} \\
\hline & 0.103 & 8.5 & $>187$ & & & \\
\hline Calciferous sandstone & - & - & $<187$ & $\begin{array}{l}<10000 \\
>5000\end{array}$ & 8.535 & 0 \\
\hline
\end{tabular}

of $220 \mathrm{~ns}$, samplings of 512 samples per trace, and 50 traces per metre. Jesus et al. (2012) collected GPR data using 80-, 200-, $400-$, and $900-\mathrm{MHz}$ antennas to characterize the radar response of the same collapsed paleocaves at different centre band frequencies. In that study, the better correlation between depth of investigation, given by lower frequency antennas, and vertical resolution, given by higher frequencies antennas, was obtained with the 200-MHz antennas, which allowed us to map karst features and host rocks as deep as $11 \mathrm{~m}$, with a vertical resolution of $4 \mathrm{~cm}$ between successive reflections. In total, $612 \mathrm{~m}$ of common-offset GPR lines using 200-MHz antennas were considered in the present study.

Two sections of the CMP array were used (yellow triangles in Fig. 2) to analyse the propagation velocity of the EM waves, which was used to estimate the dielectric constant of the col- lapsed paleocaves. The CMP data were acquired using bi-static $80-\mathrm{MHz}$ antennas with a time window of $350 \mathrm{~ns}$ and 512 samples per trace. The higher frequency $(200,400$, and $900 \mathrm{MHz})$ antennas are all mono-static. That is, we could not acquire the CMP data using these antennas. For this acquisition, the antennas were initially spaced at $1 \mathrm{~m}$, which was gradually increased by $0.2 \mathrm{~m}$ for each new reading up to a maximum interval of approximately $35 \mathrm{~m}$.

The purpose of processing the GPR data was to enhance the geophysical responses of the studied karst features using the profile that was acquired parallel to the road cut as a reference. We adopted the following processing routine using the Reflexw software package (Sandmeier 2012): a time zero correction, background removal, dewow filtering, the removal of the gain that was used in the data acquisition, the use of an energy decay 

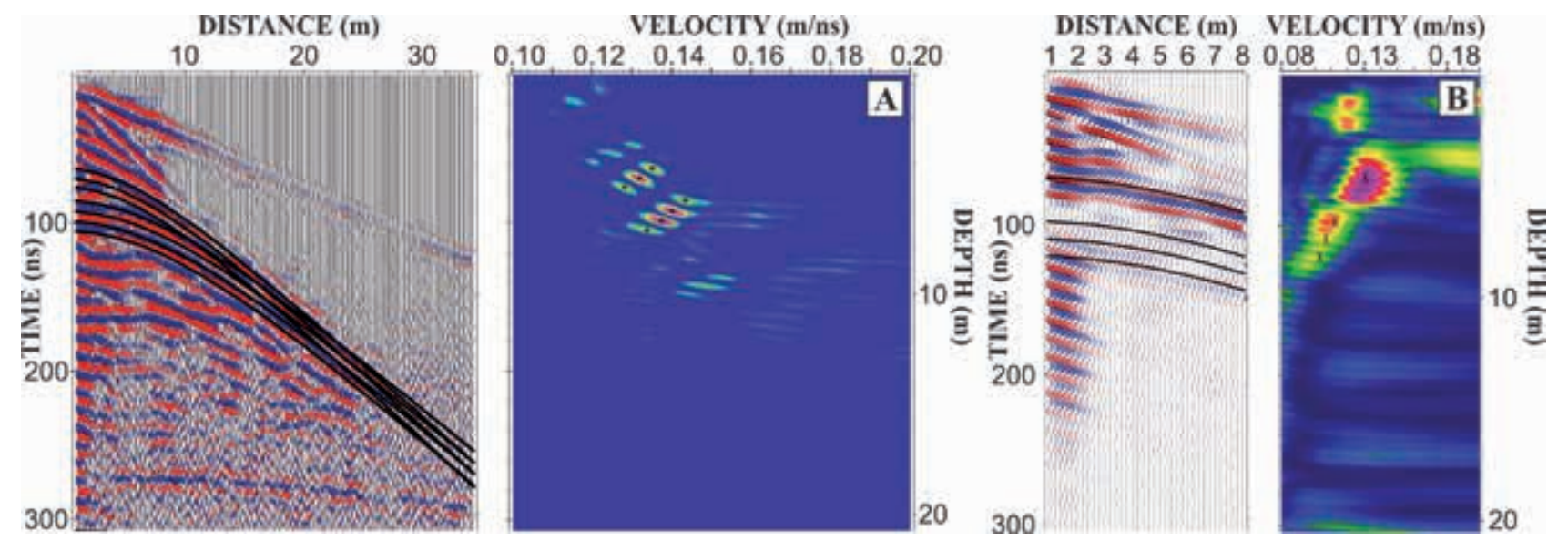

FIGURE 6

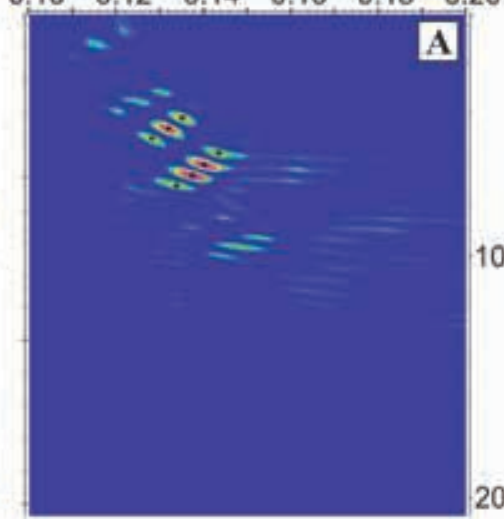

Velocity analysis of the CMP-1 (a) and CMP-2 (b) sections, obtained along the profile L1 (Fig. 3).

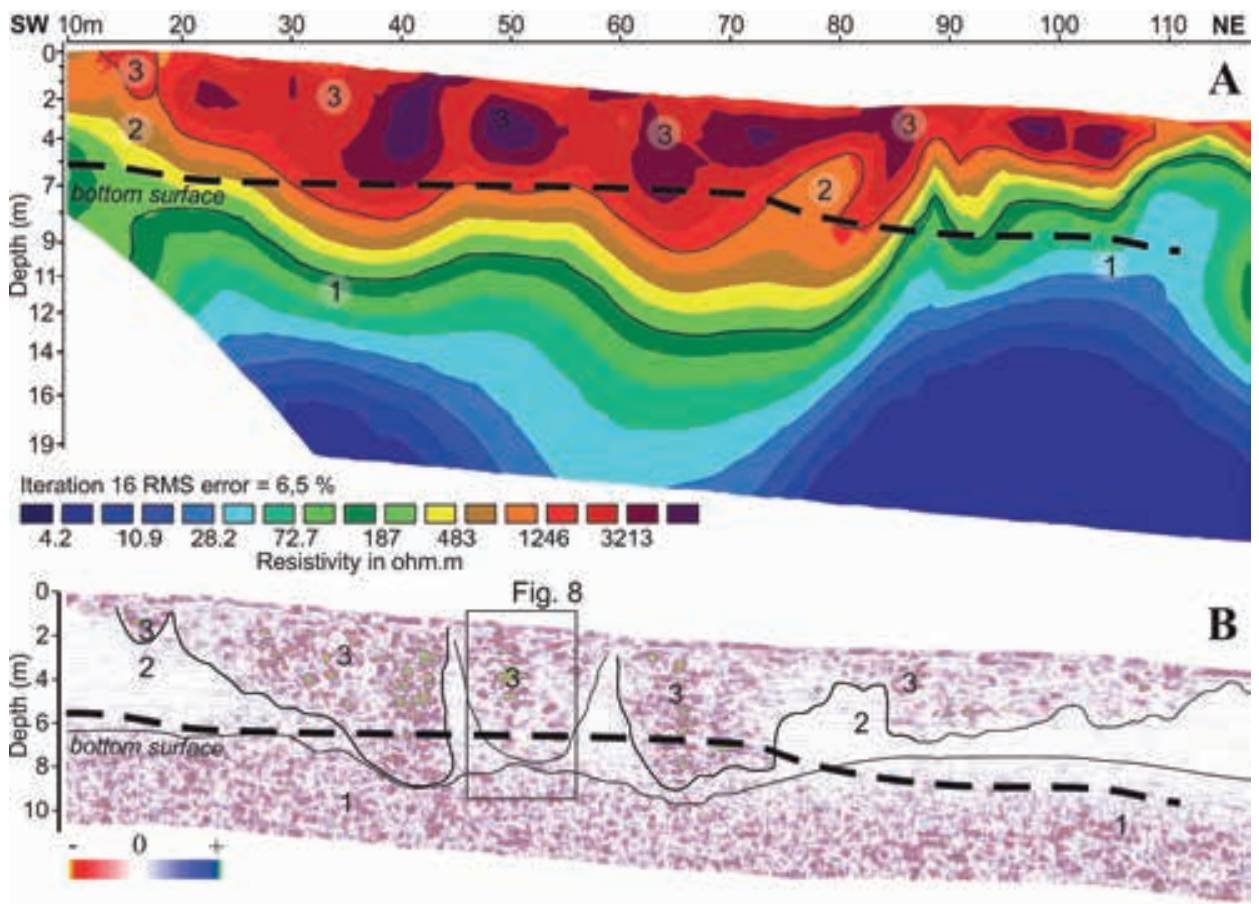

FIGURE 7

ERT (a) and GPR (b) sections of the profile L1. Geological units: 1 - fractured calciferous sandstone; 2 - carbonate soil; 3 - collapsed paleocaves.

gain, bandpass filtering, and topographic correction. Finally, the time-to-depth conversion was performed using the velocities that were obtained by applying the semblance method to the CMP data. The result of the GPR data processing is exemplified in the initial part of the profile L1 (Fig. 5). The GPR section was corrected to time zero, and the direct waves and low-frequency noise and high-frequency noise were removed. The effects that were related to EM induction and signal attenuation with depth were corrected, highlighting areas of high amplitude that were related to the paleocave regions and recovering the signal from deeper layers at a depth of approximately $11 \mathrm{~m}$.

Reis Jr. et al. (2014) improved the mapping of the collapsed paleocaves by applying several seismic attributes, such as the instantaneous frequency and amplitude, as well as the attributes that are related to the geometry of the reflectors, to the synthetic and real GPR data. The authors found that the root-square (RS) energy or the RMS amplitude attribute offered the best enhanced imaging of the paleocave system because of the high amplitudes of its internal reflectors, in contrast to the low energy of the host rocks. The RS energy attribute is based on the square root of the energy, which is calculated by dividing the sum of the squares of the amplitudes by the number of samples for a predetermined time interval (dGB Earth Sciences 2011). The length of this time window must be close to the period of the central frequency of the signal. This attribute is very sensitive to high amplitude values and thus can highlight regions of contrasting EM impedance, such that litholo- 
gies with different amplitude ranges can be distinguished between. The application of the RS energy attribute to the GPR section of the profile L1 is shown in Fig. 5c. We chose a time interval of $8 \mathrm{~ns}$, which is twice the signal wavelength from the 200-MHz antennas and better enhanced the GPR responses of the sedimentary units. The mean values of the RS energy are shown in Table 1 . In this study, we used the GPR RS energy sections to obtain the spatial extent of the paleocaves, which were compared with the resistivity distribution that was derived from the geoelectric data.

Only the dewow filter and the energy decay gain were applied in the CMP sections. The former procedure attenuated the effect of the EM induction of the antennas, and the latter procedure suppressed the effects of the GPR signal attenuation with the depth. The semblance method was used to obtain velocities between $0.103 \mathrm{~m} / \mathrm{ns}$ and $0.144 \mathrm{~m} / \mathrm{ns}$ (Fig. 6). A mean velocity of $0.106 \mathrm{~m} / \mathrm{ns}$ was chosen for the time-to-depth conversion in the GPR sections. This velocity produced the best correlation between the GPR data and the sedimentary structures that were observed in the road cut (Fig. 2). We also estimated a mean dielectric constant (or relative permittivity) of 5.0 for the material that fills the collapsed paleocaves using a mean velocity of $0.135 \mathrm{~m} / \mathrm{ns}$ (Table 1), whereas the limestone host rock (carbonate soil) was found to have higher relative dielectric permittivity of approximately 8.5 for a velocity of $0.103 \mathrm{~m} / \mathrm{ns}$.

We collected rock samples from the three primary lithofacies and measured their petrophysical properties in the laboratory. The material from the paleocaves indicated that the porosity intervals range from $30 \%$ to $40 \%$, and the permeability values range from $130 \mathrm{mD}$ to $136 \mathrm{mD}$ (Table 1). In the calciferous sandstone, these values do not exceed $9 \%$ porosity and have a permeability of almost zero. The carbonate soil is so intensively weathered that we could not obtain any reasonable measurements of its porosity and permeability. The porosity and permeability values that we found for the paleocave infill and the calciferous sandstone were similar to those that have been reported in the literature (e.g., McMechan et al. 1998; Loucks 1999). This meaningful contrast in the petrophysical properties was critical to the success of mapping the karstified features in the area of study.

\section{MAPPING OF KARST FEATURES}

Our interpretation of the GPR and electrical resistivity tomography (ERT) sections was initially based on directly associating the geophysical signal along the parallel profile with the sedimentary features that were found in the road cut (Fig. 2). This procedure also served to calibrate the depths of the reflectors and validate the interpretations of the geophysical sections. In profile L1, the three geological layers could be easily recognized by the resistivity distribution and the patterns of the GPR reflections (Fig. 7). The bottom layer (1) of calciferous sandstone is characterized by low resistivity values that range from $3 \Omega \cdot \mathrm{m}$ to $190 \Omega \cdot \mathrm{m}$ and by parallel and short reflectors with amplitudes that range from low to medium in the GPR section. In both geo- physical sections, this layer becomes shallower toward the northeast, as we observed for the cliff face. The intermediate layer of carbonate soil (2) exhibits variations in resistivity from $190 \Omega \cdot \mathrm{m}$ to $1250 \Omega \cdot \mathrm{m}$, and a uniform GPR pattern with a very low amplitude and continuous reflectors. Finally, the top layer of tufas containing the collapsed paleocaves (3) stands out from the underlying rocks because of maximum resistivity values above $1300 \Omega \cdot \mathrm{m}$ and discontinuous reflectors with high amplitudes. We could locally differentiate two radar facies inside the collapsed paleocaves (Fig. 8): radar facie R1, which is characterized by parallel reflectors of medium to high amplitude and represents layers of tufa that are deposited within the paleocaves, and radar facie R2, which contains sequences of four to eight stacked, disrupted reflectors with peak amplitudes. The chaotic geometric pattern and high amplitudes indicate regions of fractured speleothems, brecciated materials, and vugs.

In the other geophysical profiles (Fig. 9), the collapsed paleocaves and the underlying rocks were mapped using the geoelectric and GPR signatures that were described above. The geometry of the collapsed paleocaves could be identified by their predominant irregular shapes with sharp contacts, which are sometimes vertical and marked by high resistivity and highamplitude reflectors. The lateral limits of the collapsed paleocaves are marked by contact with a layer with lower resistivity and a low-amplitude GPR pattern (Figs 7 and 9) that corresponds to the carbonate soil. The base of the paleocaves is limited by the top of the calciferous sandstone layer, whose siliciclastic composition is an obstacle to the downward expansion of the karst processes. In profile L2, we could also identify the GPR patterns of radar facies R1 and R2 within the paleocaves. However, an accurate mapping of the contacts of the radar facies in these and the other GPR profiles would clearly be an arduous task and
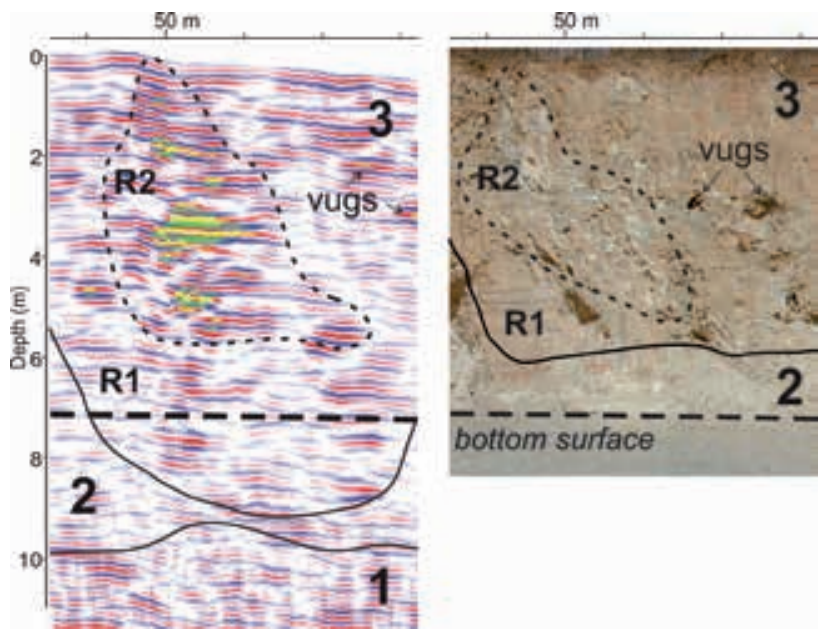

FIGURE 8

Internal radar facies of the collapsed paleocaves, associated to layered tufas (R1), brecciated material (R2) and vugs. The GPR line was carried out $3 \mathrm{~m}$ apart from the cliff face. It explains the differences between the geometries of sedimentary features and the correlated GPR radar facies. 
involve a high degree of subjectivity, particularly without constraints derived from outcrops and boreholes.

Significant variations in the geometry and concentration of the collapsed paleocaves could be identified in the geophysical profiles. In the central and northern portions of the study area, the concentration of paleocaves increases, and the paleocaves become larger and deeper, ranging from $2 \mathrm{~m}$ to more than $15 \mathrm{~m}$ deep (Fig. 9a). The paleocaves to the south are more isolated and shallower (Fig. 9b). Three-dimensional images of the resistivity and the GPR RS energy were used to better evaluate these variations in the spatial distribution of the collapsed paleocaves (Fig. 10). Therefore, the geoelectric and GPR data were interpolated using $0.5-\mathrm{m}$ regular grids and the inverse distance method that was implemented in the GPR-Slice software by Goodman (2012). High-frequency directional noise along the survey lines was effectively suppressed with fast Fourier transform $2 \mathrm{D}$ filtering by selectively blanking out the desired spatial frequency components. We used Opendtect software to generate the 3D images for the filtered grids. Within these geophysical volumes, there is a good correlation between regions of high resistivity and high GPR RS energy and the collapsed paleocaves. These karst features occupy nearly the entire superficial region of the outcrop and are only absent in the southern part and in isolated areas in the northern and northeastern sectors of the surveyed area (Fig. 10c, d). Reis Jr. et al. (2014) also had difficulty locating collapsed paleocaves in these regions, even

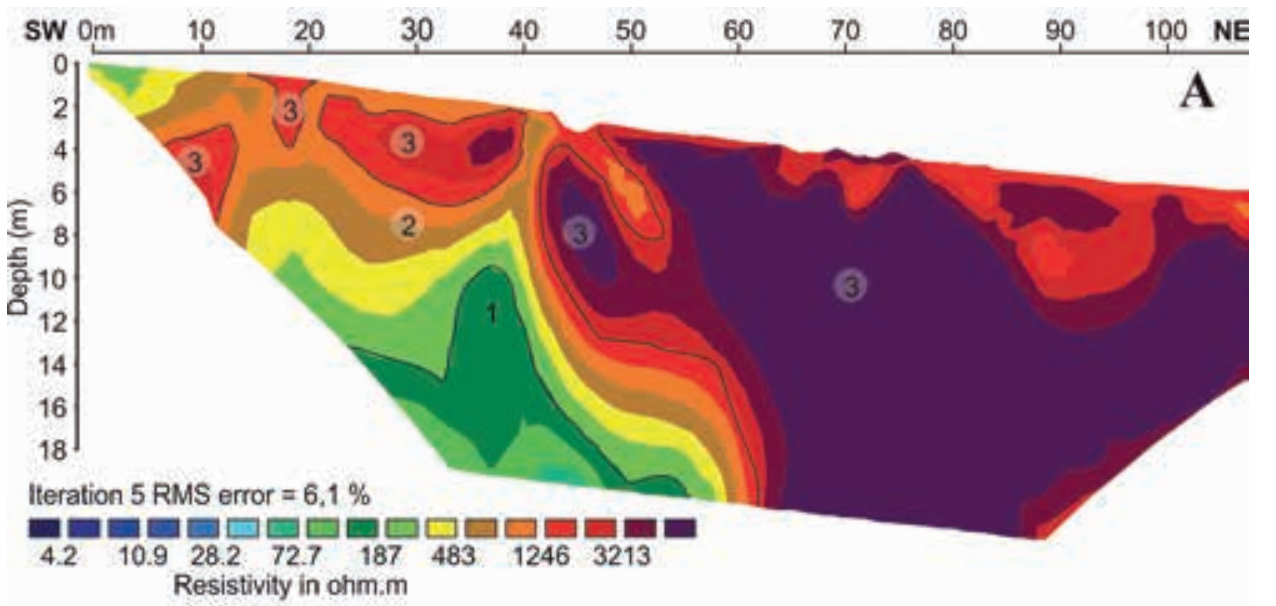

FIGURE 9

ERT and GPR sections of the profiles L2 (a) and T1 (b). Geological units: 1 - fractured calciferous sandstone; 2 - carbonate soil; 3 - collapsed paleocaves.
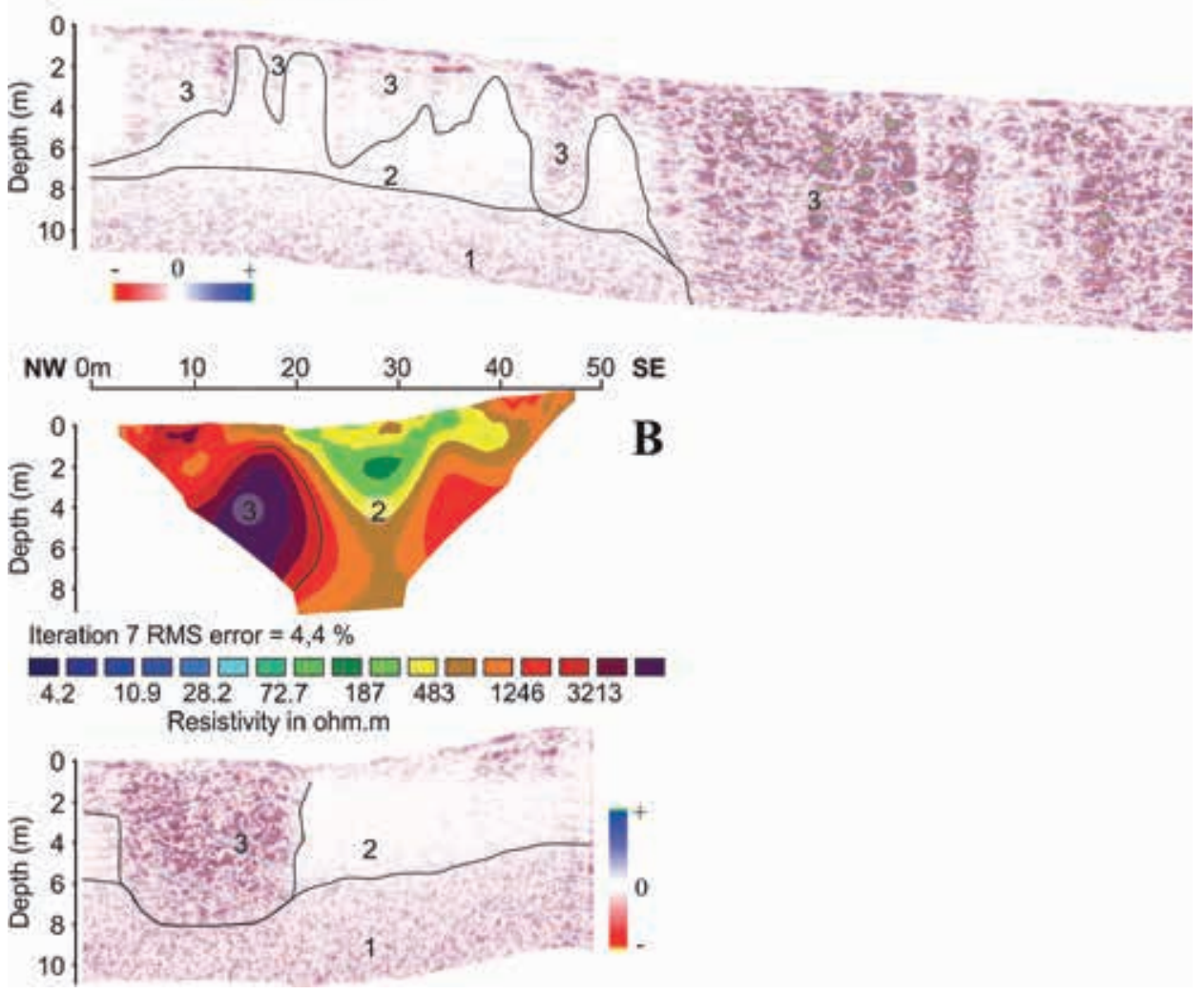


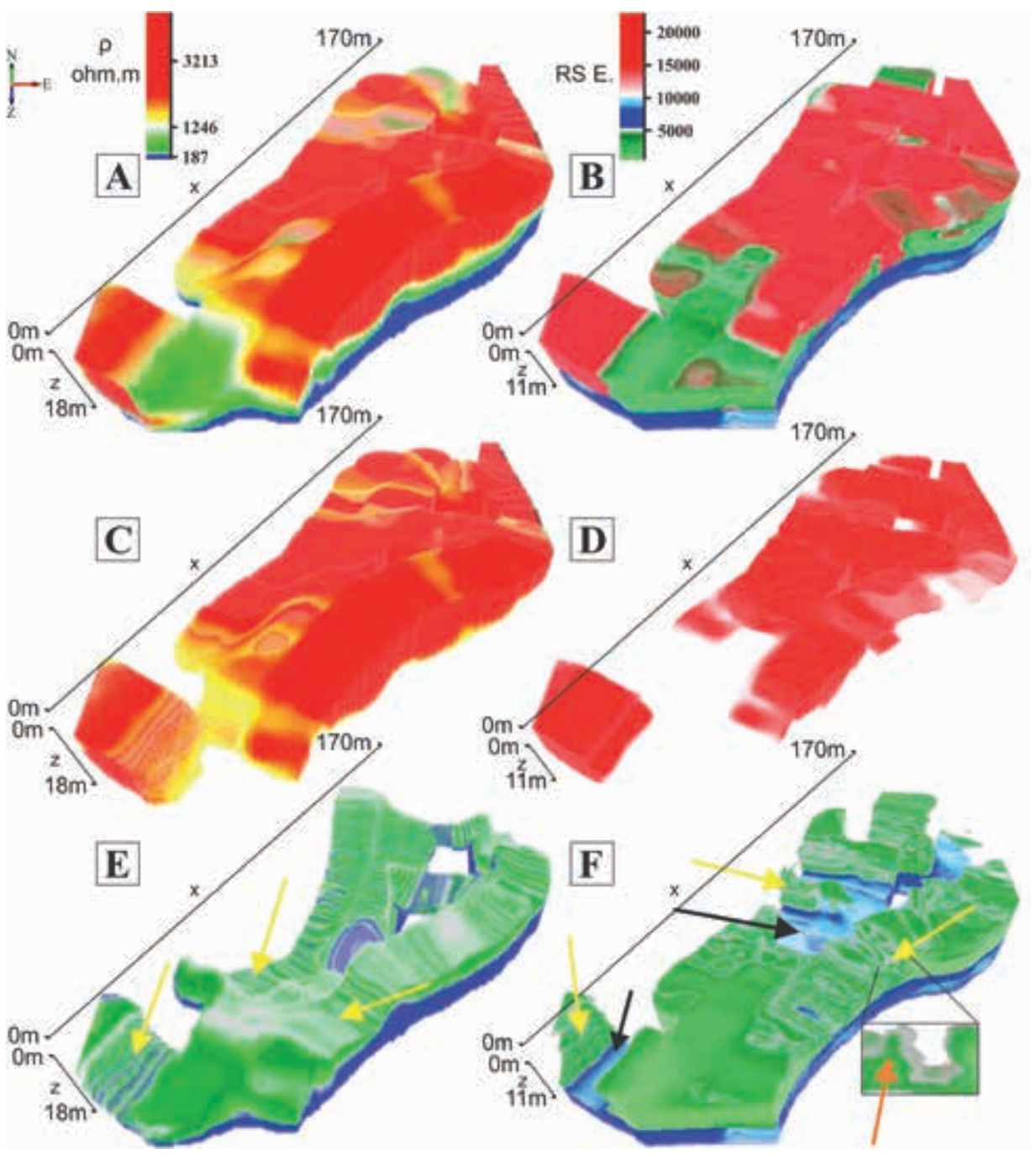

FIGURE 10

Estimated 3D distribution of the karst features identified in the resistivity sections (a, c, and e) and the GPR RS energy attribute (b, d and f). The collapsed paleocaves are identified by red and yellow, green represents the carbonate soil, and blue represents the calciferous sandstone. The yellow arrows show the locations of the paleocaves identified in the geophysical profiles (Figs 7 and 9), the black arrows indicate the locations where the paleocaves reach the top of the calciferous sandstone, and the orange arrow indicates the vertical contact of the carbonate soil with the collapsed paleocave. with the use of a denser GPR data set. The collapsed paleocaves generally become deeper toward the west, where the karstification processes were apparently more intense. In these areas, the paleocave base reaches the top of the calciferous sandstone (Fig. 10e, f).

The carbonate soil is more prominent in the southern part of the outcrop, where thicknesses of up to $7 \mathrm{~m}$ were observed (Fig. 9). In the central and northern regions, this layer is much thinner but deeper (Fig. 10e, f). This layer shows vertical contacts with the paleocaves (Figs 8, 9a, and 10f) because of the processes of cave formation and the subsequent collapse of the caves. More recent pedogenic processes caused changes in the limestone rock under more arid climatic conditions. Finally, calciferous sandstone is distributed throughout the outcrop, where the top is approximately $6 \mathrm{~m}$ deep on the eastern side and deeper westward at approximately $8 \mathrm{~m}$ (Figs 8 and 9a). The deepest top of the layer was found in the central and northern portions (Figs 9a and 10f) at the depth limit of the GPR survey, i.e., approximately $11 \mathrm{~m}$.

\section{DISCUSSION}

The collapsed paleocaves that outcrop partially on the western border of the Potiguar Basin (northeast Brazil) are characterized by positive resistivity anomalies, high GPR RS energy zones, and high-amplitude GPR reflectors (Figs 7-10). These geophysical signatures contrast with layers of lower resistivity and GPR patterns that range from low amplitude to almost transparent. The contrasts in the physical properties that create this geophysical scenario can be understood in terms of the variations in the petrophysical properties (the porosity and the permeability) between the sedimentary material that fills the paleocaves (tufas and speleothems) and the host rocks (carbonate soil and calciferous sandstone). In general, the karstification processes create empty spaces in carbonate rocks that increase their original porosity. Even caves that are filled by the re-precipitation of calcium carbonate or rock fragments that have collapsed from the cave ceiling and walls have higher effective porosity than the porosity of the host rocks. Porosities in the range of $28 \%-60 \%$ are common in carbonate rocks, such as tufas and speleothems, 


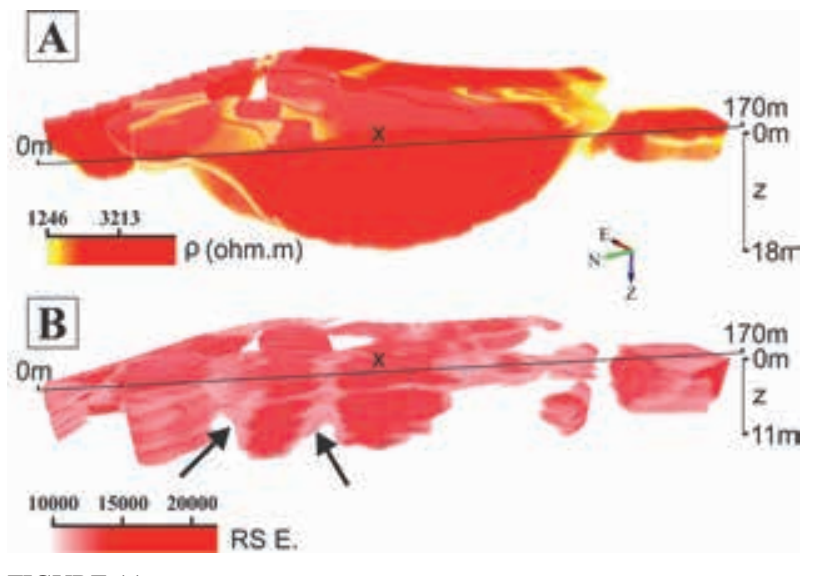

FIGURE 11

Estimated 3D distribution of the paleocave system based on the resistivity sections (a) and the GPR RS energy attribute (b). The GPR data provide better resolution to distinguish the paleocaves (black arrows).

which fill recent or old caves (McBride et al. 2012; Araújo et al. 2013). In fact, we measured the porosity of tufa samples in the paleocave in the central part of the road cut (Fig. 2) and obtained values ranging from $30 \%$ to $40 \%$ (Table 1). The calciferous sandstone (layer 1) has much lower porosity of approximately $8.5 \%$, whereas we could not reliably estimate the porosity of the carbonate soil (layer 2) because it is a friable material.

For karst rocks with high porosity, the filling of the empty spaces with air (in the vadose zone), groundwater (in the saturated zone), or residual sediments increases or decreases the rock resistivity and/or dielectric permittivity compared with that of the original rock (Pipan et al. 2003; Chalikakis et al. 2011). Given that the current water level is below $24 \mathrm{~m}$ on average in this semiarid region of Brazil (Fernandes et al. 2005), the investigated collapsed paleocaves occur in the vadose zone and are more resistive than the underlying layers, which are less porous and closer to the groundwater zone. Similarly, the high amplitude of the reflections and the anomalies in the GPR RS energy attribute inside the collapsed paleocaves arise from the strong contrast between the relative dielectric permittivity values of the cave karst infill $\left(\varepsilon_{r}=4.9\right)$ and the carbonate host rocks $\left(\varepsilon_{r}=8.3\right)$ (Table 1). As the relative dielectric permittivity of air is given as 1.0 and that of water is close to 81 (Davis and Annan 1989), the increased amount of empty space inside the paleocaves decreases the dielectric constant. Certainly, the filling of the collapsed paleocaves by brecciated and minimally cemented material contributes to local variations in the EM impedance and increases the concentration of reflectors. Conversely, the adjacent layer of limestone is a more homogeneous, friable, and non-stratified material, whose low permittivity and conductivity contrasts generate a GPR facie with low-amplitude reflectors. The pedogenic processes that more strongly affected this layer resulted in a more homogeneous rock package and, consequently, a low-amplitude GPR pattern.

The spatial distribution of the collapsed paleocave system is well delineated in terms of both the resistivity and GPR RS energy volumes (Fig. 10). However, the GPR method allowed for more accurate imaging of the internal geometry of each paleocave (Fig. 11). The GPR RS energy attribute clearly showed that the paleocaves are partially isolated in depth, forming a unique karst feature near the surface. In contrast, no isolated paleocave could be mapped using the resistivity volume, which suggests that there is a general interdigitation of the paleocaves. Other notable aspects of the GPR RS energy volume (Fig. 11b) are the vertical limits of the paleocaves, their flattened shape at the top, and the presence of sub-horizontal levels of energy inside the GPR RS energy volume. Vertical contacts of the paleocaves are expected because of the dynamics of karst processes, which develop more intensely in fractured zones. The flattened shape at the top of the karst features results from most erosive processes that have subsequently removed the upper part of the layers that enclose the paleocave system.

Finally, the GPR RS energy attribute suggests that there are bedding-plane features inside the paleocaves that could be filled with sub-horizontal material, even after the collapse of the paleocaves. Loucks (1999) has presented models of collapsed paleocaves in the Permian Basin (Texas) whose sedimentary fill consists of highly brecciated and fractured material that have been deposited into sub-horizontal strata. In the area of study, sets of sub-parallel reflectors that are a few metres long with medium to high amplitudes are associated with the quaternary tufas that have been deposited within the paleocaves. Furthermore, we could use the peaks in the amplitude to identify vugs and blocks of brecciated and fractured carbonate rocks that were chaotically arranged in the collapsed paleocaves (Fig. 8). A more detailed mapping of these radar facies could provide a high-resolution description of the paleocave facie architecture. Such a mapping would require a more detailed sedimentary facie mapping of the cliff faces, lithostratigraphic information from boreholes, and new GPR and geoelectric data acquisition with detailed 2D and 3D distributions of the boreholes combined with petrophysical data from the outcrops and core samples. These research methodologies are currently under development in the study area.

Dou et al. (2011) have stated that collapsed paleocaves play an important role in the development of stratigraphic heterogeneities and the compartmentalization of carbonate reservoirs. Important reservoirs of collapsed paleocave systems are found in the Ordovician carbonates of the Tarim and Sichuan Basins in China (Yang et al. 2012), the carbonate rocks of the Ellenburger Group of the Permian Basin in South Texas (Loucks 2001) and even in the Fort Worth Basin in North Central Texas and Southwestern Oklahoma (McDonnell et al. 2007). These carbonate reservoirs are formed by extensive systems of interconnected paleocaves, which typically have complex formation histories and well-pronounced vertical and lateral heterogeneities (Loucks 1999). The reservoirs of the Permian Basin extend over thousands of metres, with widths of several hundred metres (McMechan et al. 2002) and thicknesses on the order of a few 
tens of metres. These geometric characteristics are similar to the spatial distribution of the paleocave system of the area of study. The investigated paleocaves have thicknesses of $5 \mathrm{~m}-20 \mathrm{~m}$ and extend over a few hundred metres, both longitudinally and transversally. The paleocaves that are isolated at depth interconnect near the surface to form a large karst structure (Figs 10c, $d$ and 12) that is similar to the collapsed paleocave reservoirs in the Permian Basin.

Another important feature of the collapsed paleocave reservoirs is their high porosity. Lucia (1995) has reported an outcrop analogue to the collapsed paleocave reservoir of the Ellenburger Group of the Permian Basin in South Texas. The porosity of this outcrop is as high as $30 \%$ in the cave interiors that are filled with collapsed and cemented material. Samples of tufas and speleothems that were taken from the studied paleocaves exhibited

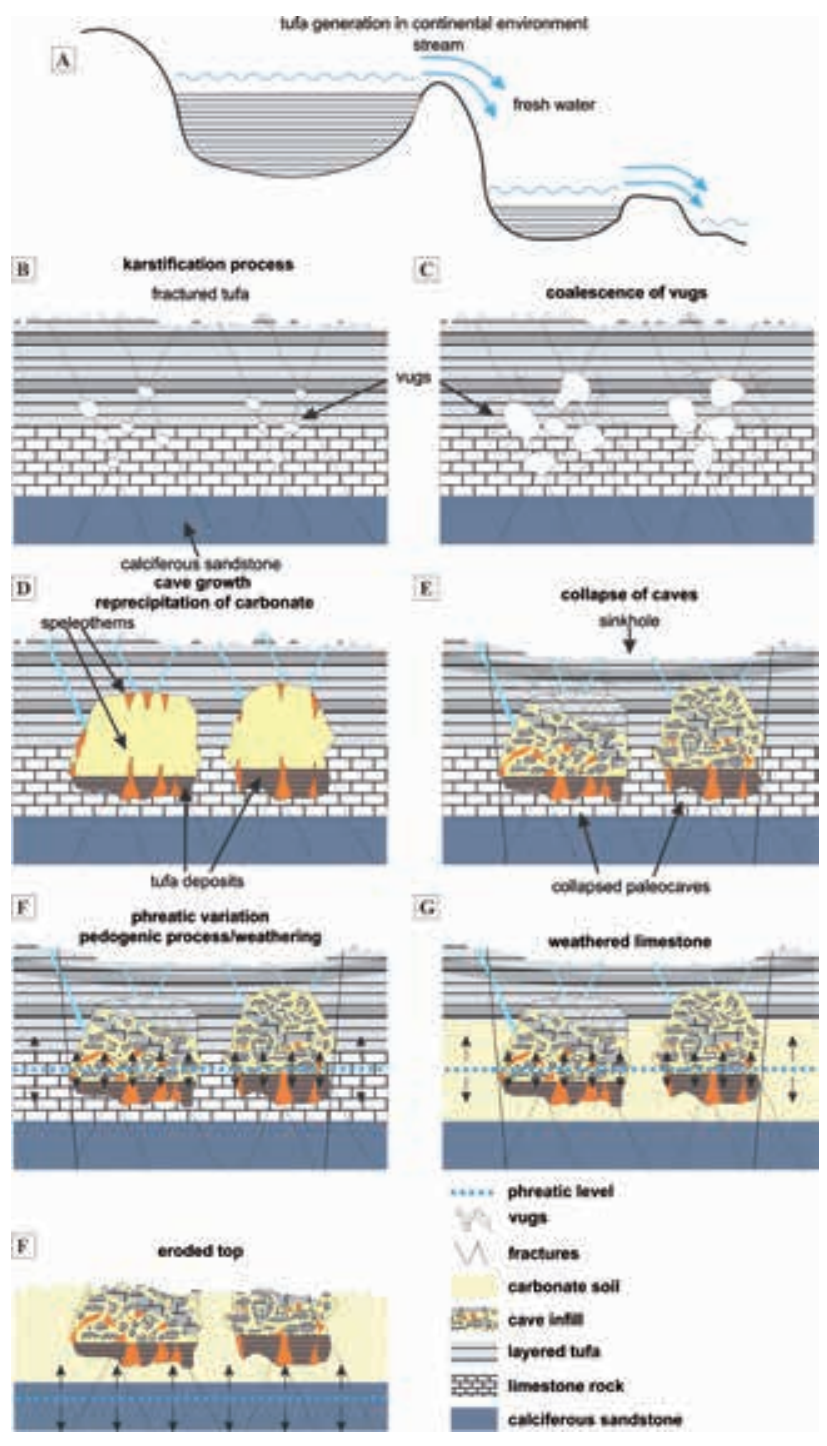

FIGURE 12

Schematic geological model showing the evolution sequence of the karst features identified in the survey area. porosities ranging from $30 \%$ to $40 \%$ (Table 1). These geometrical and petrophysical characteristics make the studied outcrop an excellent analogue to collapsed paleocave reservoirs.

In light of the geophysical results and the geological survey, we developed a preliminary evolutionary model for the karst features that partially outcrop on the western border of the Potiguar Basin. The consolidation of the carbonate platform of the Jandaíra Formation in the Neocampanian was followed by a general drop in the sea level that exposed the limestone rocks to the weathering of the continental environment. Calcium carbonate precipitated along the river system that formed over the carbonate plateau in partially dammed non-thermal waters to form narrow strips of tufa deposits (Fig. 12). Under more severe weather conditions, the layers of tufa suffered karstification and erosion. In the fractured zones, the percolation of meteoric water promoted the dissolution of the carbonate rock to create vugs and eventually caves. These caves were partially filled by the reprecipitation of the calcium carbonate in sub-horizontal strata (tufas) or vertical structures (stalagmites and stalactites).

The karstification process also affected the limestone layers underlying the tufas. The cave system continued to deepen until it reached a more resistant substrate that was formed by calciferous sandstone. In the next stage, the widespread collapse of the cave system occurred along with the appearance of dolines and sinks at the surface. Subsequent variations in the groundwater level initiated the pedogenic processes, thereby weathering the limestone layer. Through the action of capillary forces between adjacent particles, the ascending groundwater caused alterations in the limestone rock up to shallower levels. Given the higher porosity of the collapsed paleocaves, the capillary effect was insufficient to saturate the paleocaves and promote pedogenic processes at levels as shallow as the host limestone. More recently, surface erosion has resulted in the removal of parts of the paleocave system, exposing these features on the surface.

Although hydrocarbon reservoirs have not yet been found in tufas similar to those in the Potiguar Basin, the geophysical techniques that were used in this study for the $3 \mathrm{D}$ digital imaging of collapsed caves and other associated karst features can be used in similar geological settings. The developed approach can enable ducts and flow barriers to be identified and parameterized to assist reservoir engineers and geologists in better understanding this type of karst reservoir.

\section{CONCLUSIONS}

ERT and GPR sections show features that are consistent with a collapsed paleocave system that is partially exposed on the western border of the Potiguar Basin in Northeastern Brazil. Zones of high resistivity and high-amplitude GPR reflectors occur near the surface that are coincident with collapsed paleocaves that have been observed in a road cut in the contact region between the basal siliciclastic sequences and the overlying carbonate sequences. These geophysical patterns contrast with the low to medium resistivity and low-amplitude GPR 
signal of the layers of carbonate soil and the underlying calciferous sandstone. The increase in the resistivity and the decrease in the dielectric constant of the carbonate features results from the filling of the paleocaves by tufas and speleothems at a mean porosity near $35 \%$. As the paleocaves occur in the vadose zone, the empty spaces are typically filled with air and more rarely by silty-sandy sediments, thus enabling the electrical properties of the paleocaves to be differentiated from those of the host rocks.

The spatial distribution of the collapsed paleocaves was revealed in detail using ERT and GPR data. The maximum depth is approximately $10 \mathrm{~m}$ and is limited by the top of the calciferous sandstone. This layer acted as a natural barrier to the downward development of the karst processes. The individualized paleocaves increase in size from bottom to top to form an extensive system of interconnected paleocaves near the surface. The GPR sections enabled the identification of more porous zones within the collapsed paleocaves, as well as the differentiation of levels of tufas with increasing bedded character and chaotic layers from the collapse of the ceilings and walls of the caves.

The evolutionary model for the studied collapsed paleocave system involves two carbonate layers: the bottom layer is the Cretaceous limestone (Neocampanian) from the Potiguar Basin, and the top layer consists of the quaternary tufas that were deposited in the continental environment under a humid climate. Increasingly severe weather conditions triggered intense karstification processes that resulted in the emergence of the cave systems, which are partially filled with tufas and breccias and to a lesser extent by sediments that originated from surface runoff. After the widespread collapse of the paleocaves and their complete filling by tufas and breccias, variations in the groundwaterlevel-induced pedogenic processes that transformed the limestone layer at the subsurface into a white, friable mass, without preserving its depositional characteristics. Given this textural difference, the thinner Cretaceous carbonate rocks were more intensely affected by pedogenic processes than the tufas. Finally, the most recent erosive action has resulted in the removal of the most superficial parts of the collapsed paleocave layer.

The internal geometry of the collapsed paleocave system under study is reflected in the resistivity and the GPR RS energy volumes. The electrical and petrophysical properties of the rock materials that fill the paleocaves and the host layers were obtained from the geophysical data and measurements of the porosity and permeability of samples from the outcropping geological units. These results showed that the region on the west border of the Potiguar Basin is an interesting analogue to the carbonate reservoirs of collapsed paleocaves, such as those that have been mapped in the Phanerozoic Permian and Fort Worth Basins in Texas and the Tarim and Sichuan Basins in China. The high-resolution geometric and petrophysical data that have been obtained in this study could also help to characterize the carbonate reservoirs in new areas, such as the offshore hydrocarbon fields in the deep waters of the South Atlantic.

\section{ACKNOWLEDGEMENTS}

The authors would like to thank Petrobras, through the Geological Characterization and Modeling of Reservoirs Network (CARMOD), for financial support of the research project "Digital imaging of carbonate outcrops in collapsed paleocaves for elaboration of 3D static models." Comments from two anonymous reviewers greatly improved the manuscript. JAR Jr. and DLC thank Brazilian councils CAPES and $\mathrm{CNPq}$ for their respective grants.

\section{REFERENCES}

Al-fares W., Bakalowicza M., Guérinc R. and Dukhan M. 2002. Analysis of the karst aquifer structure of the Lamalou area (Hérault, France) with ground penetrating radar. Journal of Applied Geophysics 51, 97-106.

Araripe P.T. and Feijó F.J. 1994. Bacia Potiguar. Boletim de Geociências da Petrobrás 8(1), 127-141. In Portuguese.

Araújo A.M.M., Soares J.A., Dias C.H., Ribeiro G.A.V. and Medeiros L.C. 2013. Petrofísica de tufas carbonáticas da Formação Jandaíra, Bacia Potiguar. Proceedings of the 13th Congresso Internacional da Sociedade Brasileira de Geofísica, Rio de Janeiro, Brazil, Expanded Abstracts, In Portuguese.

Bagdan C.A. and Pemberton S.G. 2004. Karst breccia and bank collapse breccia: Implications for reservoir characterization of the McMurray Formation, Alberta, Canada. AAPG Bulletin 88, 13.

Burke M.J., Brennand T.A. and Perkins A.J. 2012. Transient subglacial hydrology of a thin ice sheet: insights from the Chasm esker, British Columbia, Canada. Quaternary Science Reviews 58, 30-55.

Capezzuoli E., Gandin A. and Pedley M. 2014. Decoding tufa and travertine (free water carbonates) in the sedimentary record: the state of the art. Sedimentology 61, 1-21.

Cardarelli E., Di Filippo G. and Tuccinardi E. 2006. Electrical resistivity tomography to detect buried cavities in Rome: a case study. Near Surface Geophysics 4, 387-392.

Chalikakis K., Plagnes V., Guerin R., Valois R. and Bosch F.P. 2011. Contribution of geophysical methods to karst-system exploration: an overview. Hydrogeology Journal 19(6), 1169-1180.

Davis J.L. and Annan A.P. 1989. Ground penetrating radar for high resolution mapping of soil and rock stratigraphy. Geophysical Prospecting 37, 531-551.

De Castro D.L., Medeiros W.E., Jardim de Sá E.F. and Moreira J.A.M. 1998. Mapa gravimétrico do Nordeste Setentrional do Brasil e margem continental adjacente: interpretação com base na hipótese de isostasia. Brazilian Journal of Geophysics 16(2/3), 115-131. In Portuguese.

De Groot-Hedlin C. and Constable S. 1990. Occam's inversion to generate smooth, two-dimensional models from magnetotelluric data. Geophysics 55, 1613-1624.

dGB Earth Sciences. 2011. Introduction to OpendTect: Training Manual, pp. 129. dGB Earth Sciences B.V., Enschede, Netherlands.

Dou Q., Sun Y., Sullivan C. and Guo H. 2011. Paleokarst system development in the San Andres Formation, Permian Basin, revealed by seismic characterization. Journal of Applied Geophysics 75, 379-389.

Durham L. 2009. Pre-salt has Brazil in salsa mood. AAPG Explorer 30 , 4-8.

Fernandes M.A.B., Santiago M.M.F.S., Gomes D.F., Mendes Filho J., Frischkorn H. and Lima J.O.G. 2005. A origem dos cloretos nas águas subterrâneas na Chapada do Apodi, Ceará. Águas Subterrâneas 19(1), 25-34. In Portuguese.

Ford D.C. and Williams P.W. 2007. Karst Hydrogeology and Geomorphology, pp. 562. Wiley, Chichester, U.K.

Forte E., Pipan M., Casabianca D., Di Cuia, R. and Riva A. 2012. 
Imaging and characterization of a carbonate hydrocarbon reservoir analogue using GPR attributes. Journal of Applied Geophysics 81, 76-87.

Goodman D. GPR-Slice Version 7. Program for Creating 2D/3D Subsurface Images From Raw Ground-Penetrating Radar (GPR) Data Software Manual, pp. 367. Woodland Hills, USA.

Grasmueck M., Viggiano D., Smith L. and Nyahay R. 2005. 3-D vision ground penetrating radar (GPR): reservoir anatomy beyond the outcrop surface. Abstracts of the AAPG Annual Meeting, June 19-22, 2005, Calgary, Alberta, Canada.

Grasmueck M. and Weger R. 2002. 3D GPR reveals complex internal structure of Pleistocene oolitic Sandbar. The Leading Edge 7, 634-639.

Jesus T.E.S., Reis Jr J.A., De Castro D.L. and Lima Filho F.P. 2012. Imageamento digital de paleocavernas colapsadas com ground penetrating radar. Série Científica 12, 71-84. In Portuguese.

Kerans C. 1988. Karst-controlled reservoir heterogeneity in Ellenburger Group carbonates of west Texas. AAPG Bulletin 72, 1160-1183.

Klimchouk A.B. 2007. Hypogene Speleogenesis: Hydrogeological and Morphogenetic Perspective. Special Paper no. 1, pp. 106. National Cave and Karst Research Institute, Carlsbad, NM, USA.

Kruse S., Grasmueck M., Weiss M. and Viggiano D.A. 2006. Sinkhole structure imaging in covered karst terrain. Geophysical Research Letters 33(16), L16405.1-L16405.6.

Loke M.H. 2002. 2003. RES2DINV. Rapid 2D resistivity and IP inversion using least squares method. Geotomo Software, Malaysia.

Loucks R.G. 1999. Paleocave carbonate reservoirs: origins, burial-depth modifications, spatial complexity, and reservoir implication. $A A P G$ Bulletin 83, 1795-1834.

Loucks R.G. 2001. Modern analogs for paleocave-sediment fills and their importance in identifying paleocave reservoirs. Gulf Coast Association of Geological Societies Transactions 46, 195-206.

Loucks R.G. and Anderson J.H. 1985. Depositional facies, diagenetic terranes, and porosity development in Lower Ordovician Ellenburger Dolomite, Puckettt field, West Texas. In: Carbonate Petroleum Reservoirs, (eds P.O. Roehl and P.W. Choquette), pp. 19-38. Springer-Verlag.

Lucia F.J. 1995. Lower Paleozoic cavern development, collapse, and dolomitization, Franklin Mountains, El Paso, Texas. In: Unconformities and Porosity in Carbonate Strata, (eds D.A. Budd, A.H. Saller and P.M. Harris), pp. 279-300. AAPG Memoir 63.

Matos R.M.D. 1992. The northeast Brazilian rift system. Tectonics 11(4), 766-791.

McBride J.H., Guthrie W.S., Faust D.L. and Nelson S.T. 2012. A structural study of thermal tufas using ground-penetrating radar. Journal of Applied Geophysics 81, 38-47.

McMechan G.A., Loucks R.G., Zeng X. and Mescher P.K. 1998. Ground penetrating radar imaging of a collapsed paleocave system in the Ellenburger dolomite, central Texas. Journal of Applied Geophysics 39, $1-10$.

McMechan G.A., Loucks R.G., Mescher P.A. and Zeng X. 2002. Characterization of a coalesced, collapsed paleocave reservoir analog using GPR and well-core data. Geophysics 67, 1148-1158.

McDonnell A., Loucks R.G. and Dooley T. 2007. Quantifying the origin and geometry of circular sag structures in northern Fort Worth Basin, Texas: paleocave collapse, pull-apart fault systems, or hydrothermal alteration? AAPG Bulletin 4, 603-622.

McClymont A.F., Green A.G., Streich R., Horstmeyer H., Tronicke J., Nobes D.C. et al. 2008. Visualization of active faults using geometric attributes of 3D GPR data: an example from the Alpine Fault Zone, New Zealand. Geophysics 73(2), B11-B23.

Miller C.R., James N.P. and Bone Y. 2012. Prolonged carbonate diagenesis under an evolving late cenozoic climate; Nullarbor Plain, southern Australia. Sedimentary Geology 261-262, 33-49.

Pessoa Neto O.C., Soares U.M., Silva J.G.F., Roesner E.H., Florêncio C.P. and Souza C.A.V. 2007. Bacia Potiguar. Boletim de Geociências da Petrobras 15(2), 357-369. In Portuguese.

Pipan M., Forte E., Guangyou F. and Finetti I. 2003. High-resolution GPR imaging and joint characterisation in limestones. Near Surface Geophysics 1, 39-55.

Reis Jr J.A., De Castro D.L., Jesus T.E.S. and Lima Filho F.P. 2014. Characterization of collapsed paleocave systems using GPR attributes. Journal of Applied Geophysics 103, 43-56.

Reyes Perez Y.A., Lima Filho F.P., Menezes L., Porsani J.L., Appi C.J., Araujo V.D. et al. 2003. Caracterização da geometria de depósitos sedimentares da formação Açu na borda sudoeste da Bacia Potiguar, NE do Brasil. Revista de Geologia (Fortaleza) 16(1), 19-34. In Portuguese.

Roth M.J.S., Mackey J.R., Mackey C. and Nyquist J.E. 2002. A case study of the reliability of multielectrode earth resistivity testing for geotechnical investigations in karst terrains. Engineering Geology 65, 225-232.

Roth M.J.S. and Nyquist J.E. 2003. Evaluation of multi-electrode earth resistivity testing in karst. ASTM Geotechnical Testing Journal 26, 167-178.

Sandmeier K.J. 2012. ReflexW version 7. Program for the Processing of Seismic, Acoustic or Electromagnetic Reflection, Refraction and Transmission Data. User's Manual, pp. 578. Karlsruhe, Germany,

Steven H., Lumen S., Naresh K., Adriano S. and Sujate V. 2010. Tupi's conjugate: new pre-salt plays in the Angolan offshore. AAPG Houston 2010, Houston, TX, abstracts.

Schoor M. 2002. Detection of sinkholes using 2D electrical resistivity imaging. Journal of Applied Geophysics 50, 393-399.

Takayama P., Menezes P. and Travassos J. 2008. High-Resolution 3D GPR imaging of carbonate analogue reservoirs. Proceedings of 33rd International Geological Congress, August 6-14, 2008, Oslo, pp. 234-237.

White W.B. 2007. A brief history of karst hydrogeology: contributions of the NSS. Journal of Cave and Karst Studies 69, 13-26.

Yang P., Sun S., Liu Y., Li H., Dan G. and Jia H. 2012. Origin and architecture of fractured-cavernous carbonate reservoirs and their influences on seismic amplitudes. The Leading Edge 31(2), 140-150.

Zeng H.L., Loucks R., Janson X., Wang G.Z., Xia Y.P., Yuan B.H. et al. 2011. Three-dimensional seismic geomorphology and analysis of the Ordovician Paleokarst drainage system in the Central Tabei Uplift, northern Tarim Basin, Western China. Bulletin American Association of Petroleum Geologists 95, 2061-2083.

Zhou W., Beck B.F. and Adams A.L. 2002. Effective electrode array in mapping karst hazards in electrical resistivity tomography. Environmental Geology 42, 922-928.

Zhou W., Beck B.F. and Stephenson J.B. 1999. Application of electrical resistivity tomography and natural-potential technology to deliniate potential sinkhole collapse areas in a covered karst terrane. In: Hydrogeology and Engineering Geology of Sinkholes and Karst, (eds B.F. Beck, A.J. Pettit and J.G. Herring), pp. 187-193. Balkema, Rotterdam. 